\title{
Out-of-Pocket Spending Not Associated with Oral Oncolytic Survival Benefit
}

\author{
Lisa S. Rotenstein, MD, MBA; Stacie B. Dusetzina, PhD; and Nancy L. Keating, MD, MPH
}

\begin{abstract}
BACKGROUND: With total and out-of-pocket spending for oral oncolytics rising, there is increased interest in choosing oncology treatments based on their clinical value relative to cost.

OBJECTIVE: To determine if out-of-pocket spending varied for higher versus lower benefit oral oncology drugs reimbursed by commercial insurers.

METHODS: This study was a retrospective analysis of commercial insurer prescription drug claims filed between 2007 and 2014 for 13 oral oncolytics approved before 2009 . We calculated mean monthly out-of-pocket payment for each fill by patient. We then categorized oral oncolytics by their overall and progression-free survival benefits for each FDA-approved indication, using evidence from published studies. We assessed the relationship of survival benefit with mean monthly out-of-pocket payment, adjusting for demographic and plan characteristics.
\end{abstract}

RESULTS: Our population included 44,113 patients aged 18-65 years (mean 52.5 [SD 9.4]) with a cancer diagnosis who filled 731,354 prescriptions. The most commonly represented oncolytics were imatinib (37.4\% of fills), lenalidomide ( $17.7 \%$ of fills), and dasatinib ( $10.0 \%$ of fills). Approximately $32.3 \%$ of fills were for drug-indication pairs with an overall survival benefit of $4+$ years. In adjusted analyses, there was no clear pattern to suggest that out-of-pocket payments differed with drug indication-specific survival benefits. Drugs for indications providing $>0$ to 1 year of overall survival benefit were significantly more likely to have a lower out-of-pocket payment versus those prescribed off-label, but there were no significant differences in out-of-pocket payments between drugs and associated indications in any other survival category versus drugs used off-label.

CONCLUSIONS: Out-of-pocket payments for oral oncolytics were not clearly related to indication-specific value in commercially insured patients. This finding suggests that despite increased attention to value- and indicationbased drug pricing, cost sharing for oral oncolytics does not currently reflect these goals.

J Manag Care Spec Pharm. 2018;24(6):494-502

Copyright $\odot 2018$, Academy of Managed Care Pharmacy. All rights reserved.

\section{What is already known about this subject}

Spending on cancer drugs, particularly oral oncolytics, continues to rise in the United States, with 1 study showing an average monthly out-of-pocket spending increase from $\$ 88$ in 2001 to $\$ 198$ in 2011.

There is interest in choosing treatments based on their value, and institution of lower-cost sharing levels for interventions with greater efficacy has been shown to increase adherence and improve clinical outcomes.

\section{What this study adds}

Out-of-pocket payments for oral oncolytics from 2007-2014 were not clearly related to indication-specific value.

Despite increasing interest in value-based pricing, out-of-pocket payment design is not congruent with the goal of aligning costs with health outcomes.

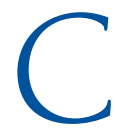

ancer drug costs continue to rise in the United States, ${ }^{1}$ and spending on targeted oral oncolytics has increased particularly rapidly, with mean monthly expenditures in the year of product launch increasing from $\$ 1,869$ in 2000 to $\$ 11,325$ in 2014. ${ }^{2}$ Rising drug prices and expanded use of cost sharing have translated to higher out-of-pocket spending for targeted oral oncolytics., ${ }^{2,3}$ For example, 1 study found that average out-of-pocket monthly expenditures rose from $\$ 88$ in 2001 to $\$ 198$ in $2011 .^{4}$

Concurrently, there is increasing interest in choosing treatments based on their value-or health outcomes relative to their $\operatorname{cost}^{5}$-with definitions of outcomes in oncology integrating clinical benefits, toxicities, and patient preferences. ${ }^{6,7}$ Evidence of the relationship between drug prices and outcomes in oncology is mixed but largely suggests that overall price is not correlated with benefit. ${ }^{8-10}$ With regards to prices that patients see, there is a lack of evidence that insurers have employed cost sharing to preferentially encourage use of higher- versus lowerefficacy oncology drugs. Institution of lower cost-sharing levels for interventions with greater evidence of efficacy is known as value-based insurance design and has previously been shown to increase adherence to medications and improve clinical outcomes. ${ }^{11}$ Given the known inverse relationship between out-ofpocket spending and adherence to or continuation of oncology drugs, ${ }^{12,13}$ use of value-based cost sharing could potentially drive patient adherence to high-efficacy oral oncolytics and thus enhance outcomes.

Within this context, we sought to describe out-of-pocket spending by patients with commercial insurance who had a diagnosis of cancer during 2007-2014 and were treated with oral cancer drugs approved before 2009. We specifically assessed if patients using drugs with higher versus lower benefit had lower out-of-pocket spending, with benefit defined in terms of overall or progression-free survival as per the American Society of Clinical Oncology's (ASCO) 2016 Value Framework. ${ }^{6}$ 


\section{Methods}

\section{Data and Patients}

We used the MarketScan Commercial Claims and Encounters Database for 2007-2014 to examine drug use and expenditures among cancer patients who had filled any orally administered, targeted nonhormonal anticancer medications approved before 2009.,14 We restricted our analysis to the 13 drugs approved before 2009 to ensure availability of 5 years of data for analysis, thus, allowing for adjustment for changes in spending over time. The MarketScan database represents $>50$ million employees and their dependents enrolled in commercial health insurance plans sponsored by approximately 100 large and medium-sized U.S.-based employers. About $56 \%$ of the nonelderly U.S. population was covered by employer-sponsored coverage in 2014, making the MarketScan database largely representative of our population of interest. ${ }^{15}$ We identified 731,354 prescription drug claims filled by 44,113 patients with a cancer diagnosis in the year of the fill. We excluded 5,063 claims with patient or plan payment $<\$ 0$ or days supplied $<0$.

\section{Measures}

Out-of-Pocket Expenditures. We summed monthly copayments, coinsurance, and deductibles for each fill. We adjusted fills for $>1$-month supply to a single month supply to generate mean monthly total out-of-pocket payments. We did not consider employee contributions to commercial health insurance coverage via monthly paycheck deductions because we sought to estimate the cost to patients of an oral oncolytic at the time of prescription fill. Patient cost sharing at the point of service is a formulary tool that may influence a patient's use of a prescription drug. ${ }^{16}$

Clinical Benefit of Oral Oncolytics. We categorized drugs by overall survival benefit (defined as time from randomization in a trial to death) and progression-free survival benefit (defined as time from randomization in a trial to disease progression or death; used if overall survival data were lacking) for each indication approved by the U.S. Food and Drug Administration (FDA) for the particular oncolytic (as described in the product label for that oncolytic). We examined evidence from randomized controlled clinical trials that compared the drug against standard of care or placebo for each particular FDA-approved indication. We reported overall or progression-free survival benefit as a relative survival benefit (i.e., overall survival or progression-free survival with drug minus overall or progression-free survival with standard of care or placebo, depending on what was reported in the included trial). If multiple similar trials were available for a drug and indication, we selected the trial presenting the largest estimate of survival differences between patients receiving treatment versus control. If median overall survival or progression-free survival were not reached in published trials (most commonly due to high overall survival), we used estimates from cost-effectiveness analyses and, where appropriate, focused on the survival measure for which a significant effect had been shown in randomized controlled trials.

Drugs and associated indications were partitioned into the following 8 categories of increasing evidence for benefit, based on the relative distribution of survival estimates for all fills: (1) off-label use (i.e., prescribed to a patient with a diagnosis that was not an FDA-approved indication for that drug); (2) no survival benefit for an on-label indication; (3) >0-5 months progression-free survival benefit; (4) $>5-10$ months progression-free survival benefit; (5) $10+$ months progression-free survival benefit; (6) >0-12 months overall survival benefit; (7) $>12-48$ months overall survival benefit; and (8) 48+ months overall survival benefit. If a drug was associated with statistically significant overall survival and progression-free survival benefits, it was only put into an overall survival category, given the clinical superiority of overall survival benefits over progression-free survival benefits. The distribution of each drug and its associated assignment into these categories, as well as the study from which information about benefit was derived, is described in Table 1. Each of these categories was assigned a sequential numeric code, which was applied individually to each fill for each patient based on the drug and associated cancer diagnosis for that fill.

As an example of this process, pazopanib is approved for use in soft tissue sarcoma. In a 2012 study by van der Graaf et al., ${ }^{17}$ use of the drug was associated with a progression-free survival benefit of 4.6 months, while use of placebo was associated with a progression-free survival benefit of 1.6 months. We thus calculated the relative progression-free survival benefit as 3 months. This placed pazopanib for an indication of soft-tissue sarcoma in category number 3 for $>0-5$ months of progressionfree survival benefit.

In the case of imatinib, since median overall and progression-free survival was not reached even in trials with longerterm follow-up, ${ }^{18}$ we used estimates of these metrics from economic modeling studies based on randomized controlled trial data. ${ }^{19}$ Given that randomized controlled trials had demonstrated an overall survival benefit of imatinib versus interferon alpha, we defined the relative survival benefit of imatinib as the difference between the 19.1 remaining life-years associated with first-line imatinib versus the 9.1 life-years associated with first-line interferon alpha. ${ }^{19}$

Covariates. For each patient in each year, we documented age, health plan type, and census region, as reported in the MarketScan database. We also calculated previous year comorbidity based on the Klabunde modification of the Charlson comorbidity score, using diagnoses reported in MarketScan for each patient. ${ }^{20}$ We also measured total monthly drug reimbursement (out-of-pocket and plan payments for each fill 


\begin{tabular}{|c|c|c|c|c|c|}
\hline Drug & Year & Indication & Survival Benefit Category & Source & Survival Comparisons \\
\hline \multirow[t]{6}{*}{ Imatinib } & 2001 & $\begin{array}{l}\text { Philadelphia chromo- } \\
\text { some positive CML }\end{array}$ & OS $4+$ years & Reed et al., $2008^{19}$ & $\begin{array}{l}229.2 \text { months (treatment) vs. } 109.2 \text { months } \\
\text { (control) OS benefit }\end{array}$ \\
\hline & 2002 & $\begin{array}{l}\text { Gastrointestinal stro- } \\
\text { mal tumors }\end{array}$ & PFS $10+$ months & Howell et al., $2008^{32}$ & $\begin{array}{l}45.3 \text { months (treatment) vs. } 5.6 \text { months } \\
\text { (control) PFS benefit }\end{array}$ \\
\hline & 2006 & $\begin{array}{l}\text { Philadelphia chromo- } \\
\text { some positive ALL }\end{array}$ & OS $>1-4$ years & Botteman et al., $2006^{33}$ & $\begin{array}{l}51.72 \text { months (treatment) vs. } 13.2 \text { months } \\
\text { (control) OS benefit }\end{array}$ \\
\hline & 2006 & $\begin{array}{l}\text { Myelodysplastic/ } \\
\text { myeloproliferative } \\
\text { diseases }\end{array}$ & $\begin{array}{l}\text { No OS/PFS benefit in RCT. } \\
\text { Approval based on white } \\
\text { blood cell/genetic responses } \\
\text { in single drug study. }\end{array}$ & & N/A \\
\hline & 2006 & $\begin{array}{l}\text { Chronic eosinophilic } \\
\text { leukemia }\end{array}$ & $\begin{array}{l}\text { No OS/PFS benefit in RCT. } \\
\text { Approval based on white } \\
\text { blood cell response in single } \\
\text { drug study. }\end{array}$ & & N/A \\
\hline & 2006 & $\begin{array}{l}\text { Dermatofibrosarcoma } \\
\text { protuberans }\end{array}$ & $\begin{array}{l}\text { No PFS/OS benefit in RCT. } \\
\text { Approval based on decrease } \\
\text { in tumor size in single-drug } \\
\text { study. }\end{array}$ & & N/A \\
\hline Gefitinib & 2003 & $\begin{array}{l}\text { EGFR positive non- } \\
\text { small cell lung cancer }\end{array}$ & PFS $>5-10$ months & Maemondo et al., $2010^{34}$ & $\begin{array}{l}10.8 \text { months (treatment) vs. } 5.4 \text { months } \\
\text { (control) PFS benefit }\end{array}$ \\
\hline \multirow[t]{2}{*}{ Erlotinib } & $\begin{array}{l}2004 \\
2013\end{array}$ & $\begin{array}{l}\text { Non-small cell lung } \\
\text { cancer }\end{array}$ & PFS $>5-10$ months & Zhou et al., $2015^{35}$ & $\begin{array}{l}13.1 \text { months (treatment) vs. } 4.6 \text { months } \\
\text { (control) PFS benefit }\end{array}$ \\
\hline & 2005 & Pancreatic cancer & OS $>0-1$ year & Moore et al., 200736 & $\begin{array}{l}6.4 \text { months (treatment) vs. } 6 \text { months } \\
\text { (control) OS benefit }\end{array}$ \\
\hline \multirow[t]{3}{*}{ Sorafenib } & 2005 & Renal cell carcinoma & PFS $>0-5$ months & Escudier et al., $2007^{37}$ & $\begin{array}{l}5.5 \text { months (treatment) vs. } 2.8 \text { months } \\
\text { (control) PFS benefit }\end{array}$ \\
\hline & 2007 & Liver carcinoma & OS $>0-1$ year & Llovet et al., $2008^{38}$ & $\begin{array}{l}10.7 \text { months (treatment) vs. } 7.9 \text { months } \\
\text { (control) OS benefit }\end{array}$ \\
\hline & 2013 & $\begin{array}{l}\text { Thyroid cancer refrac- } \\
\text { tory to radioactive } \\
\text { iodine }\end{array}$ & PFS $>0-5$ months & Brose et al., 201439 & $\begin{array}{l}10.8 \text { months (treatment) vs. } 5.8 \text { months } \\
\text { (control) PFS benefit }\end{array}$ \\
\hline \multirow[t]{2}{*}{ Lenalidomide } & 2006 & Multiple myeloma & OS $>0-1$ year & Dimopolous et al., $2009^{40}$ & $\begin{array}{l}38 \text { months (treatment) vs. } 31.6 \text { months } \\
\text { (control) OS benefit }\end{array}$ \\
\hline & 2013 & Mantle cell lymphoma & PFS $>0-5$ months & Trněný et al., $2016^{41}$ & $\begin{array}{l}8.7 \text { months (treatment) vs. } 5.2 \text { months } \\
\text { (control) PFS benefit }\end{array}$ \\
\hline \multirow[t]{2}{*}{ Dasatinib } & 2006 & $\begin{array}{l}\text { Philadelphia chromo- } \\
\text { some positive CML }\end{array}$ & OS $>1-4$ years & Hoyle et al., $2011^{42}$ & $\begin{array}{l}78 \text { months (treatment) vs. } 32.2 \text { months } \\
\text { (control) OS benefit }\end{array}$ \\
\hline & 2006 & $\begin{array}{l}\text { Philadelphia chromo- } \\
\text { some positive ALL }\end{array}$ & $\begin{array}{l}\text { No PFS/OFS benefit in } \\
\text { comparator-controlled trial. } \\
\text { Approval based on white } \\
\text { blood cell response in single } \\
\text { drug study. }\end{array}$ & & N/A \\
\hline \multirow[t]{3}{*}{ Sunitinib } & 2006 & $\begin{array}{l}\text { Advanced renal cell } \\
\text { carcinoma }\end{array}$ & OS $>0-1$ year & Motzer et al., $2009^{43}$ & $\begin{array}{l}26.4 \text { months (treatment) vs. } 21.3 \text { months } \\
\text { (control) OS benefit }\end{array}$ \\
\hline & 2006 & $\begin{array}{l}\text { Gastrointestinal stro- } \\
\text { mal tumors }\end{array}$ & PFS $>0-5$ months & Demetri et al., $2006^{44}$ & $\begin{array}{l}5.5 \text { months (treatment) vs. } 1.4 \text { months } \\
\text { (control) PFS benefit }\end{array}$ \\
\hline & 2011 & $\begin{array}{l}\text { Pancreatic neuroendo- } \\
\text { crine tumors }\end{array}$ & PFS $>5-10$ months & Favire et al., $2017^{45}$ & $\begin{array}{l}12.6 \text { months (treatment) vs. } 5.8 \text { months } \\
\text { (control) PFS benefit }\end{array}$ \\
\hline Thalidomide & 2006 & Multiple myeloma & PFS $10+$ months & Rajkumar et al., $2006^{46}$ & $\begin{array}{l}22.4 \text { months (treatment) vs. } 6.5 \text { months } \\
\text { (control) PFS benefit }\end{array}$ \\
\hline Vorinostat & 2007 & $\begin{array}{l}\text { Cutaneous T-cell } \\
\text { lymphoma }\end{array}$ & $\begin{array}{l}\text { No PFS/OS benefit in RCT. } \\
\text { Approval based on decrease } \\
\text { in tumor size in single-drug } \\
\text { studies. }\end{array}$ & & N/A \\
\hline Lapatinib & 2007 & Breast cancer & PFS $>5-10$ months & Johnston et al., 200947 & $\begin{array}{l}8.2 \text { months (treatment) vs. } 3 \text { months } \\
\text { (control) PFS benefit }\end{array}$ \\
\hline Nilotinib & 2007 & $\begin{array}{l}\text { Philadelphia chromo- } \\
\text { some positive CML }\end{array}$ & OS $4+$ years & Hoyle et al., $2011^{42}$ & $\begin{array}{l}81.3 \text { months (treatment) vs. } 24.4 \text { months } \\
\text { (control) OS benefit }\end{array}$ \\
\hline
\end{tabular}




\begin{tabular}{|c|c|c|c|c|c|}
\hline Drug & Year & Indication & Survival Benefit Category & Source & Survival Comparisons \\
\hline \multirow[t]{2}{*}{ Pazopanib } & 2009 & $\begin{array}{l}\text { Advanced renal cell } \\
\text { carcinoma }\end{array}$ & PFS $>0-5$ months & Sternberg et al., $2013^{48}$ & $\begin{array}{l}9.2 \text { months (treatment) vs. } 4.2 \text { months } \\
\text { (control) PFS benefit }\end{array}$ \\
\hline & 2012 & Soft tissue sarcoma & PFS $>0-5$ months & van der Graaf et al., $2012^{17}$ & $\begin{array}{l}4.6 \text { months (treatment) vs. } 1.6 \text { months } \\
\text { (control) PFS benefit }\end{array}$ \\
\hline \multirow[t]{6}{*}{ Everolimus } & 2009 & Renal cell carcinoma & PFS $>0-5$ months & Motzer et al., $2010^{49}$ & $\begin{array}{l}4.9 \text { months (treatment) vs. } 1.9 \text { months } \\
\text { (control) PFS benefit }\end{array}$ \\
\hline & 2011 & $\begin{array}{l}\text { Neuro-endocrine } \\
\text { tumors of pancreatic } \\
\text { origin }\end{array}$ & PFS $>5-10$ months & Yao et al., $2011^{50}$ & $\begin{array}{l}11 \text { months (treatment) vs. } 4.6 \text { months } \\
\text { (control) PFS benefit }\end{array}$ \\
\hline & 2011 & $\begin{array}{l}\text { Neuro-endocrine } \\
\text { tumors of GI or lung } \\
\text { origin }\end{array}$ & PFS $>5-10$ months & Yao et al., $2016^{51}$ & $\begin{array}{l}11 \text { months (treatment) vs. } 3.9 \text { months } \\
\text { (control) PFS benefit }\end{array}$ \\
\hline & 2012 & Breast cancer & PFS $>0-5$ months & Piccart et al., 201452 & $\begin{array}{l}7.8 \text { months (treatment) vs. } 3.2 \text { months } \\
\text { (control) PFS benefit }\end{array}$ \\
\hline & 2012 & Renal angiomyolipoma & $\begin{array}{l}\text { No PFS/OS benefit in RCT. } \\
\text { Approval based on decrease } \\
\text { in tumor size in RCT. }\end{array}$ & & N/A \\
\hline & 2012 & $\begin{array}{l}\text { Subependymal giant } \\
\text { cell astrocytoma }\end{array}$ & $\begin{array}{l}\text { No PFS/OS benefit in RCT. } \\
\text { Approval based on decrease } \\
\text { in tumor size in RCT. }\end{array}$ & & N/A \\
\hline \multicolumn{6}{|c|}{$\begin{array}{l}{ }^{a} \text { No significant OS benefit shown in RCTs. } \\
\text { bSignificant OS benefit shown versus historical controls in trials not reporting median OS. } \\
{ }^{C P}=0.051 \text {, considered significant. } \\
\text { ALL=acute lymphocytic leukemia; } C M L=\text { chronic myelogenous leukemia; EGFR=epidermal growth factor receptor; N/A=not available; OS = overall survival; } \\
P F S=\text { progression-free survival; } R C T=\text { randomized controlled trial. }\end{array}$} \\
\hline
\end{tabular}

adjusted to a per-month value) to account for differences in drug prices. Variables are categorized in Table 2.

\section{Analysis}

After describing out-of-pocket expenditures by drug benefit and patient characteristics, we estimated a 2-part model, ${ }^{21}$ predicting changes in out-of-pocket payments by drug survival benefit and adjusting for the previously described covariates. The first part of the model consisted of a logit function that assessed the association of drug survival benefit with having any out-ofpocket spending (vs. none). The second part used a generalized linear model with a gamma distribution and a log-link function to assess the association of drug survival benefit with level of non-zero out-of-pocket spending. Estimates from these 2 models were combined using a margins function. ${ }^{21}$

In sensitivity analyses, we conducted stratified analyses, first, considering overall survival as a continuous variable among patients treated with drugs with evidence for an overall survival benefit and, second, considering progression-free survival as a continuous variable among patients treated with drugs, with evidence for only progression-free survival benefit. Finally, in a sensitivity analysis, we conducted a version of the original 2-part model excluding the top 5\% of monthly outof-pocket spending claims. All dollars were inflation adjusted to 2014 U.S. dollars based on the medical component of the Consumer Price Index.
Because pricing decisions are often made at launch when only 1 indication for a drug is known, it is possible that cost sharing may be more closely related to the first indication's benefit rather than that of subsequent indications. ${ }^{9}$ Accordingly, in a secondary analysis, we reassigned the survival benefit for each drug and all its associated indications based on the benefits associated with the drug's first approved indication. Finally, we repeated analyses within subgroups of drugs or indications, including among tyrosine kinase inhibitors only, among drugs for treating renal cell carcinoma, and for a single drug (i.e., lenalidomide) when considering all of its indications.

Two-sided $P$ values $<0.05$ were considered statistically significant. Data were analyzed using SAS version 9.4 (SAS Institute, Cary, NC). This study was deemed not human subjects research by the Harvard University Institutional Review Board.

\section{Results}

The 44,113 patients who filled 731,354 prescriptions for oral anticancer drugs between 2007 and 2014 had a mean age of 52.5 (standard deviation [SD] 9.4) years, and approximately half of the patients were male (Table 2). The most commonly represented oncolytics were imatinib (37.4\% of fills), lenalidomide (17.7\% of fills), and dasatinib (10.0\% of fills). Overall, $18.3 \%$ of prescription fills were for drugs used off-label, and $1.2 \%$ were for drugs and associated indications with no survival benefit. Approximately $6.3 \%$ of fills were for drugs 


\begin{tabular}{|c|c|}
\hline Characteristic & Percentage \\
\hline \multicolumn{2}{|l|}{ Age, years } \\
\hline $18-35$ & 6.7 \\
\hline $36-45$ & 12.8 \\
\hline $45-55$ & 33.5 \\
\hline $56-65$ & 47.0 \\
\hline \multicolumn{2}{|l|}{ Gender } \\
\hline Male & 52.3 \\
\hline Female & 47.7 \\
\hline \multicolumn{2}{|l|}{ Region } \\
\hline Northeast & 17.0 \\
\hline Midwest & 24.7 \\
\hline South & 38.6 \\
\hline West & 18.5 \\
\hline Unknown & 1.3 \\
\hline \multicolumn{2}{|l|}{ Charlson comorbidity score } \\
\hline 0 & 79.7 \\
\hline 1 & 12.6 \\
\hline 2 & 5.0 \\
\hline $3+$ & 2.7 \\
\hline \multicolumn{2}{|l|}{ Health plan type } \\
\hline Consumer-driven/high deductible & 7.0 \\
\hline Comprehensive & 4.1 \\
\hline $\begin{array}{l}\text { Exclusive provider organization/health } \\
\text { maintenance organization }\end{array}$ & 16.0 \\
\hline Point of service/point of service with capitation & 7.4 \\
\hline Preferred provider organization & 61.1 \\
\hline Unknown health plan & 4.4 \\
\hline
\end{tabular}

and associated indications with $>0-5$ months of progressionfree survival benefit; $9.7 \%$ for drugs and associated indications with $>5-10$ months of progression-free survival benefit; and $5.4 \%$ for those drugs and associated indications with 10+ months of progression-free survival benefit. Finally, 16.8\% of fills were for drugs and associated indications with $>0-1$ year of overall survival benefit; $10.1 \%$ for those with $>1-4$ years of overall survival benefit; and $32.3 \%$ for those with more than 4 years of overall survival benefit. Monthly per-fill out-of-pocket payments ranged from $\$ 0$ to $\$ 14,167.30$, with a mean of $\$ 82.82$ (SD \$353.45). The mean monthly total (plan plus patient) was $\$ 5,884$ (SD \$2,901.46). Table 3 depicts numbers of patient-fills and mean out-of-pocket payment by drug and indication.

In adjusted analyses, there was no clear pattern to suggest that out-of-pocket payments differed with drug indicationspecific survival benefits (Table 4). While drugs for indications providing $>0-1$ year of overall survival benefit were significantly more likely to have a lower copayment versus those prescribed off-label, there were no significant differences in out-of-pocket payments between drugs and associated indications in any other survival category versus drugs used off-label. Having a more recent year of fill was associated with lower out-of-pocket spending $(P<0.001)$. In addition, fills for drugs with higher total costs (plan plus patient payment) were associated with higher out-of-pocket spending $(P<0.001$; Table 4). Notably, the correlation coefficient for total drug cost and survival benefit was 0.06 , suggesting that total drug prices were not associated with benefit).

Results of sensitivity analyses including only (a) patients filling drugs with evidence of an overall survival benefit or (b) patients filling drugs with a progression-free survival benefit and examining overall or progression-free survival as continuous variables similarly revealed no significant relationship between out-of-pocket payment and survival benefit (change in mean monthly out-of-pocket spending for each additional month of progression-free survival $=0.11,95 \%$ confidence interval $[\mathrm{CI}]-0.42-0.63, P=0.69$; change for each additional month of overall survival $=0.01,95 \% \mathrm{CI}=-0.04-0.05, P=0.77$ )

Results of sensitivity analyses excluding payments in the top $5 \%$ yielded results similar to those in our primary model (not shown). Our findings also held within subgroups of drugs or indications such as among only tyrosine kinase inhibitors, only drugs for renal cell carcinoma, and only for lenalidomide when considering all of its indications (data not shown; available from authors).

Finally, analyses examining survival benefit based on the benefit reported for the drug's first approved indication also showed no association of out-of-pocket payments with benefit (Table 5).

\section{Discussion}

Despite consistently rising out-of-pocket spending for oral oncolytics and increasing interest in value-based pricing, ${ }^{4,6,7}$ we found that out-of-pocket payments for oral oncolytics from 2007-2014 were not clearly related to indication-specific survival benefit in a commercial population. Although drugs with >0-1 year of overall survival benefit were associated with significantly lower out-of-pocket spending, there was no difference in out-of-pocket payments for drugs in any other survival category versus drugs used off-label. In addition, while previous analyses have examined drug pricing in relation to first indication survival benefit, ${ }^{9}$ our analysis did not show any relationship between the survival benefit of the first approved indication and out-of-pocket payment.

Cancer therapy is associated with significant financial toxicity, including bankruptcy, ${ }^{22}$ and there is evidence that beneficiaries with higher-out-of-pocket costs are more likely to discontinue cancer therapy. ${ }^{12,13}$ Notably, substantial financial toxicity of cancer therapy has been associated with worse outcomes, including early mortality. ${ }^{23}$ Value-based insurance designs have been shown to improve adherence in nononcology clinical areas, ${ }^{24-26}$ and ideally, cost sharing could be aligned to encourage greater use of and adherence to high-value cancer treatments. However, we saw no association between 
Out-of-Pocket Spending Not Associated with Oral Oncolytic Survival Benefit

\begin{tabular}{|c|c|c|c|c|c|}
\hline \multirow{7}{*}{$\frac{\text { Drug }}{\text { Imatinib }}$} & \multirow{2}{*}{$\begin{array}{l}\text { Year } \\
2001\end{array}$} & \multirow{2}{*}{$\frac{\text { Indication }}{\text { Philadelphia chromosome positive CML }}$} & \multirow{2}{*}{$\begin{array}{c}\begin{array}{c}\text { Number of } \\
\text { Patient-Fills }\end{array} \\
196,801\end{array}$} & \multicolumn{2}{|c|}{$\begin{array}{l}\text { Mean OOP Payment } \\
\text { in \$ (SD) }\end{array}$} \\
\hline & & & & 70.9 & $(281.92)$ \\
\hline & 2002 & Gastrointestinal stromal tumors & 26,030 & 85.24 & $(372.36)$ \\
\hline & 2006 & Philadelphia chromosome positive ALL & 15,693 & 52.40 & $(199.88)$ \\
\hline & 2006 & Myelodysplastic/myeloproliferative diseases & N/A & \multicolumn{2}{|c|}{ N/A } \\
\hline & 2006 & Chronic eosinophilic leukemia & 197 & 39.85 & $(40.42)$ \\
\hline & 2006 & Dermatofibrosarcoma protuberans & N/A & \multicolumn{2}{|c|}{ N/A } \\
\hline Gefitinib & 2003 & EGFR positive non-small cell lung cancer & 692 & 36.23 & $(72.23)$ \\
\hline \multirow[t]{2}{*}{ Erlotinib } & 2004,2013 & Non-small cell lung cancer & 38,805 & 82.67 & $(316.30)$ \\
\hline & 2005 & Pancreatic cancer & 7,113 & 75.26 & $(304.46)$ \\
\hline \multirow[t]{3}{*}{ Sorafenib } & 2005 & Renal cell carcinoma & 5,427 & 98.70 & $(327.40)$ \\
\hline & 2007 & Liver carcinoma & 8,161 & 95.00 & $(366.92)$ \\
\hline & 2013 & Thyroid cancer refractory to radioactive iodine & 1,593 & 72.70 & $(237.90)$ \\
\hline \multirow[t]{2}{*}{ Lenalidomide } & 2006 & Multiple myeloma & 86,472 & 102.32 & $(449.10)$ \\
\hline & 2013 & Mantle cell lymphoma & 7,933 & 148.43 & $(748.56)$ \\
\hline \multirow[t]{2}{*}{ Dasatinib } & 2006 & Philadelphia chromosome positive CML & 57,907 & 86.53 & $(369.52)$ \\
\hline & 2006 & Philadelphia chromosome positive ALL & 7,494 & 71.95 & $(366.88)$ \\
\hline \multirow[t]{3}{*}{ Sunitinib } & 2006 & Advanced renal cell carcinoma & 21,086 & 88.15 & $(378.53)$ \\
\hline & 2006 & Gastrointestinal stromal tumors & 4,084 & 69.31 & $(311.94)$ \\
\hline & 2011 & Pancreatic neuroendocrine tumors & 4,010 & 103.83 & $(399.96)$ \\
\hline Thalidomide & 2006 & Multiple myeloma & 13,107 & 82.34 & $(347.54)$ \\
\hline Vorinostat & 2007 & Cutaneous T-cell lymphoma & 923 & 77.23 & $(294.50)$ \\
\hline Lapatinib & 2007 & Breast cancer & 21,023 & 68.19 & $(231.41)$ \\
\hline Nilotinib & 2007 & Philadelphia chromosome positive CML & 39,612 & 104.73 & $(432.55)$ \\
\hline \multirow[t]{2}{*}{ Pazopanib } & 2009 & Advanced renal cell carcinoma & 8,613 & 89.87 & $(398.24)$ \\
\hline & 2012 & Soft tissue sarcoma & 2,728 & 100.73 & $(382.97)$ \\
\hline \multirow[t]{6}{*}{ Everolimus } & 2009 & Renal cell carcinoma & 5,773 & 92.89 & $(403.11)$ \\
\hline & 2011 & Neuro-endocrine tumors of pancreatic origin & 2,799 & 76.55 & $(310.37)$ \\
\hline & 2011 & Neuro-endocrine tumors of GI or lung origin & 3,529 & 69.90 & $(271.83)$ \\
\hline & 2012 & Breast cancer & 9,614 & 96.83 & $(387.76)$ \\
\hline & 2012 & Renal angiomyolipoma & 90 & 39.31 & $(145.59)$ \\
\hline & 2012 & Subependymal giant cell astrocytoma & 17 & 12.47 & $(20.44)$ \\
\hline
\end{tabular}

$A L L=$ acute lymphocytic leukemia; $C M L=$ chronic myelogenous leukemia; $E G F R=$ epidermal growth factor receptor; N/A=not available; OOP=out of pocket; $S D=$ standard deviation

out-of-pocket payments and drug survival benefit. This finding suggests that despite some payers and pharmacy benefit managers announcing or considering value-based drug pricing, 7,27 the complex U.S. drug reimbursement and distribution system still does not lend itself to cost sharing that reflects value., ${ }^{7,28}$

Previous work has demonstrated that out-of-pocket spending increased substantially between 2001 and 2011 for oral oncolytics and that Medicare enrollees are more likely to discontinue more expensive cancer drugs., ${ }^{4} 12$ In addition, several payers have publicly cited interest in value-based pricing for oncology drugs. ${ }^{27,29}$ However, the fact that a relationship does not exist between value as defined by survival and out-of-pocket costs has not been previously demonstrated in the oncology realm. Possibly reflecting the increasing prevalence of oral chemotherapy parity laws, ${ }^{30,31}$ we observed lower out-of-pocket payments for fills in more recent calendar years. As expected, we observed higher out-of-pocket payments for more expensive drugs.

\section{Limitations}

Our study has limitations that need to be considered. Given the composition of the MarketScan database, we studied only commercial health insurance claims for individuals with employer-sponsored insurance; out-of-pocket payments and their relation to drug benefit may differ for other payers, including individuals enrolled in Medicare Part D. Although the MarketScan database provides some information about employee health plan types, it does not provide more granular data regarding copay, coinsurance, or drug coverage arrangements for individual plans, which limited our ability to adjust for more granular differences in coverage. The database also 


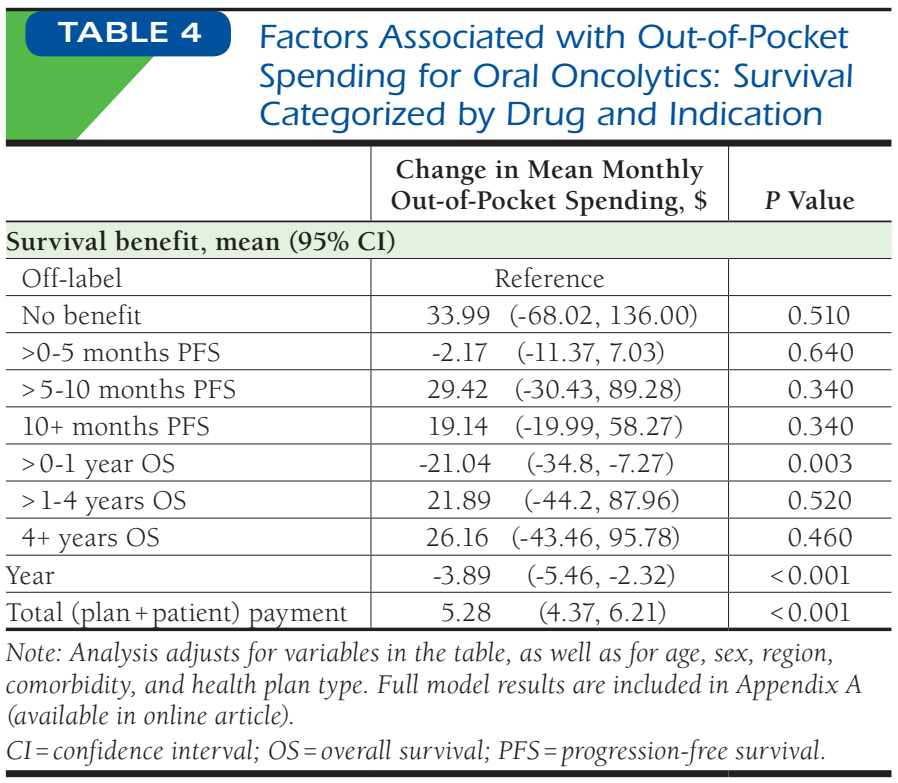

does not provide information regarding employee contributions to health insurance coverage, such as paycheck deductions. We were also limited to evaluating filled prescriptions, which by nature of patient-pharmacy interactions and the composition of the MarketScan database means those for which claims were paid in full. It is possible that patients prescribed lower value treatments were less likely to fill them if faced with high out-of-pocket costs. Prescriptions not filled were excluded from our analysis, thus, potentially excluding a segment of our population of interest facing significant costs.

Our analysis included only oral oncolytics approved through 2009, so findings could differ for more recently approved drugs, particularly given the recent focus on the value of care delivered in the context of health care reform. In addition, we described value in terms of survival benefit. This metric has been designated as a cornerstone of defining value in ASCO's 2016 Value Framework. ${ }^{6}$ However, there are certainly other aspects that contribute to a therapy's clinical value, including safety, tolerability, and ease of use. Further analyses should examine the relationship between these additional measures and out-of-pocket costs.

Finally, since information about cancer stage is not available in the MarketScan database, it was assumed that any drug used for a particular FDA-approved indication was used for the correct stage of disease based on oncologist expertise. While this was largely true, there may have been exceptions not captured in our analysis.

\section{Conclusions}

Our study demonstrated that for commercially insured patients, out-of-pocket payments were not associated with indicationspecific survival for oral oncolytics approved before 2009 .

\begin{tabular}{|c|c|c|}
\hline \multicolumn{3}{|c|}{$\begin{array}{l}\text { Factors Associated with Out-of-Pocket } \\
\text { Spending for Oral Oncolytics: Survival } \\
\text { Categorized by Drug's First Approved } \\
\text { Indication }\end{array}$} \\
\hline & $\begin{array}{l}\text { Change in Mean Monthly } \\
\text { Out-of-Pocket Spending, \$ }\end{array}$ & $P$ Value \\
\hline \multicolumn{3}{|l|}{ Survival benefit, mean (95\% CI) } \\
\hline Off-label & Reference & \\
\hline No benefit & $300.63(-6484.95,7086.20)$ & 0.930 \\
\hline$>0-5$ months PFS & $159.01 \quad(-3575.37,3893.39)$ & 0.930 \\
\hline$>5-10$ months PFS & $1094.58(-24981.46,27170.62)$ & 0.930 \\
\hline $10+$ months PFS & $-56.44 \quad(-608.30,495.42)$ & 0.840 \\
\hline$>0-1$ year OS & $-56.47 \quad(-608.20,495.27)$ & 0.840 \\
\hline$>1-4$ years OS & $469.23(-10186.67,11125.13)$ & 0.930 \\
\hline $4+$ years OS & $429.99 \quad(-9226.77,10086.76)$ & 0.930 \\
\hline Year & $-3.85 \quad(-5.68,2.03)$ & $<0.001$ \\
\hline Total (plan+ patient) payment & $(2.93,6.85)$ & $<0.001$ \\
\hline
\end{tabular}

Note: Analysis controls for variables in the table, as well as for age, sex, region, comorbidity, and health plan type. Full model results are included in Appendix B (available in online article).

$C I=$ confidence interval; $O S=$ overall survival; $P F S=$ progression - free survival

This finding highlights opportunities for commercial health insurers to address the complexities of implementing valuebased cost sharing for oncolytics in a health care landscape that will increasingly emphasize benefit reaped for dollars spent.

\section{Authors}

LISA S. ROTENSTEIN, MD, MBA, and NANCY L. KEATING, MD, MPH, Department of Health Care Policy, Harvard Medical School, and Department of Medicine, Brigham and Women's Hospital, Boston, Massachusetts. STACIE B. DUSETZINA, PhD, Division of Pharmaceutical Outcomes and Policy, Eshelman School of Pharmacy and Gillings School of Global Public Health, and Lineberger Comprehensive Cancer Center, University of North Carolina, Chapel Hill.

AUTHOR CORRESPONDENCE: Nancy L. Keating, MD, MPH, Department of Health Care Policy, 180 Longwood Ave., Boston, MA 02115. Tel.: 617.432.3093; E-mail: Keating@hcp.med.harvard.edu.

\section{DISCLOSURES}

This project was supported by Research Scholar Grant RSGI-14-030-01CPHPS from the American Cancer Society; the NIH Building Interdisciplinary Research Careers in Women's Health (BIRCWH) K12 Program; the North Carolina Translational and Clinical Sciences Institute (UL1TR001111) Grant: and K24CA181510 from the National Cancer Institute. The authors have no disclosures.

Data from this study were presented at the 2017 American Society for Clinical Oncology Annual Meeting on June 5, 2017, in Chicago, Illinois. 


\section{REFERENCES}

1. IMS Institute for Health Informatics. Developments in cancer treatments, market dynamics, patient access, and value. May 2015. Available at: https:// www.keionline.org/sites/default/files/IIHI_Oncology_Trend_Report_2015. pdf. Accessed April 11, 2018.

2. Dusetzina SB. Drug pricing trends for orally administered anticancer medications reimbursed by commercial health plans, 2000-2014. JAMA Oncol. 2016;2(7):960-61

3. Kaiser Family Foundation. 2015 Employee health benefits survey. September 22, 2015. Available at: https://www.kff.org/report-section/ehbs2015-section-one-cost-of-health-insurance/. Accessed April 12, 2018.

4. Shih Y-CT, Smieliauskas F, Geynisman DM, Kelly RJ, Smith TJ. Trends in the cost and use of targeted cancer therapies for the privately insured nonelderly: 2001 to 2011. J Clin Oncol. 2015;33(19):2190-96.

5. Porter ME. What is value in health care? N Engl J Med. 2010;363(26):2477-81.

6. Schnipper LE, Davidson NE, Wollins DS, et al. Updating the American Society of Clinical Oncology Value Framework: revisions and reflections in response to comments received. J Clin Oncol. 2016;34(24):2925-34.

7. Bach PB. Indication-specific pricing for cancer drugs. JAMA. 2014;312(16): 1629-30.

8. Howard D, Chernew M, Abdelgawad T, Smith G, Sollano J, Grabowski D. New anticancer drugs associated with large increases in costs and life expectancy. Health Aff (Millwood). 2016;35(9):1581-87.

9. Howard DH, Bach PB. Pricing in the market for anticancer drugs. J Econ Perspect. 2015;29(1):139-62

10. Mailankody S, Prasad V. Five years of cancer drug approvals: innovation, efficacy, and costs. JAMA Oncol. 2015;1(4):1-2.

11. Gibson TB, Maclean JR, Chernew ME, Fendrick AM, Baigel C. Valuebased insurance design: benefits beyond cost and utilization. Am J Manag Care. 2015;21(1):32-35.

12. Kaisaeng N, Harpe SE, Carroll NV. Out-of-pocket costs and oral cancer medication discontinuation in the elderly. J Manag Care Spec Pharm. 2014:20(7):669-75. Available at: https://www.jmcp.org/doi/10.18553/ jmcp.2014.20.7.669.

13. Streeter SB, Schwartzberg L, Husain N, Johnsrud M. Patient and plan characteristics affecting abandonment of oral oncolytic prescriptions. I Oncol Pract. 2011;7(3 Suppl):46s-51s

14. Memorial Sloan Kettering Cancer Center. Cancer drug costs for a month of treatment at initial Food and Drug Administration approval [Table]. Available at: https://www.mskcc.org/sites/default/files/node/25097/ documents/120915-drug-costs-table.pdf. Accessed April 12, 2018.

15. Long M, Rae M, Claxton G. Trends in employer-sponsored insurance offer and coverage rates, 1999-2014. Kaiser Family Foundation. March 21, 2016. Available at: http://www.kff.org/private-insurance/issue-brief/trendsin-employer-sponsored-insurance-offer-and-coverage-rates-1999-2014. Accessed April 12, 2018.

16. Academy of Managed Care Pharmacy. Pharmacy benefit design Updated February 2016. Available at: http://www.amcp.org/WorkArea/ DownloadAsset.aspx?id=20949. Accessed April 12, 2018.

17. van der Graaf WT, Blay JY, Chawla SP, et al. Pazopanib for metastatic soft-tissue sarcoma (PALETTE): a randomised, double-blind, placebo-controlled phase 3 trial. Lancet. 2012;379(9829):1879-86.

18. Druker BJ, Guilhot F, O'Brien SG, et al. Five-year follow-up of patients receiving imatinib for chronic myeloid leukemia. N Engl J Med. 2006:355(23):2408-17.

19. Reed SD, Anstrom KJ, Li Y, et al. Updated estimates of survival and cost effectiveness for imatinib versus interferon- $\alpha$ plus low-dose cytarabine for newly diagnosed chronic-phase chronic myeloid leukaemia. Pharmacoeconomics. 2008;26(5):435-46.
20. Klabunde CN, Potosky AL, Legler JM, Warren JL. Development of a comorbidity index using physician claims data. J Clin Epidemiol. 2000;53(12):1258-67.

21. Belotti F, Deb P, Manning W, Norton E. Two-part models. Stata J. 2015;15(1):3-20

22. Ramsey S, Blough D, Kirchhoff A, et al. Washington state cancer patients found to be at greater risk for bankruptcy than people without a cancer diagnosis. Health Aff (Millwood). 2013;32(6):1143-52.

23. Ramsey SD, Bansal A, Fedorenko CR, et al. Financial insolvency as a risk factor for early mortality among patients with cancer. J Clin Oncol. 2016;34(9):980-86

24. Frank MB, Fendrick AM, He Y, et al. The effect of a large regional health plan's value-based insurance design program on statin use. Med Care. 2012:50(11):934-39.

25. Choudhry NK, Avorn J, Glynn RJ, et al. Full coverage for preventive medications after myocardial infarction. N Engl J Med. 2011;365(22):2088-97.

26. Chernew ME, Shah MR, Wegh A, et al. Impact of decreasing copayments on medication adherence within a disease management environment. Health Aff (Millwood). 2008;27(1):103-12.

27. Centers for Medicare \& Medicaid Services. CMS proposes to test new Medicare Part B prescription drug models to improve quality of care and deliver better value for Medicare beneficiaries. March 8, 2016. Available at: https://www.cms.gov/Newsroom/MediaReleaseDatabase/Fact-sheets/2016Fact-sheets-items/2016-03-08.html. Accessed April 30, 2018.

28. Pearson S, Dreitlein B, Henshall C. Indication-specific pricing of pharmaceuticals in the United States healthcare system. Institute for Clinical and Economic Review. March 2016. Available at: https://icer-review.org/ wp-content/uploads/2016/03/Final-Report-2015-ICER-Policy-Summit-onIndication-specific-Pricing-March-2016_revised-icons.pdf. Accessed April 12, 2018.

29. Livingston S. Value-based contracts key to solving U.S. drug pricing "crisis." Modern Healthcare. June 9, 2017. Available at: http://www.modernhealthcare.com/article/20170609/NEWS/170609875. Accessed April 12, 2018.

30. Kirkwood KM. The state of cancer care in America, 2016: a report by the American Society of Clinical Oncology. J Oncol Pract. 2016;12(4):339-38.

31. Dusetzina SB, Huskamp HA, Winn AN. Out-of-pocket and health care spending changes for patients using orally administered anticancer therapy after adoption of state parity laws. JAMA Oncol. November 9, 2017 [Epub ahead of print]. Available at: https://jamanetwork.com/journals/jamaoncology/article-abstract/2661763. Accessed April 30, 2018.

32. Howell JE, Szabatura AH, Hatfield Seung A, Nesbit SA. Characterization of the occurrence of ifosfamide-induced neurotoxicity with concomitant aprepitant. J Oncol Pharm Pract. 2008;14(3):157-62.

33. Botteman MF, Tran KT, Stephens JM. Cost effectiveness of adding imatinib to chemotherapy in adult patients with Philadelphia chromosome positive acute lymphoblastic leukemia (Ph+ALL): an exploratory analysis for the UK. Value Health. 2006;9(6):A289. Available at: https://www.valueinhealthjournal.com/issue/S1098-3015(10)X6056-9?page=6. Accessed May 9, 2018.

34. Maemondo M, Inoue A, Kobayashi K, et al. Gefitinib or chemotherapy for non-small cell lung cancer with mutated EGFR. N Engl J Med. 2010;362(25):2380-88

35. Zhou C, Wu YL, Chen G, et al. Final overall survival results from a randomized, phase III study of erlotinib versus chemotherapy as first-line treatment of EGFR mutation-positive advanced non-small-cell lung cancer (OPTIMAL, CTONG-0802). Ann Oncol. 2015;26(9):1877-83.

36. Moore MJ, Goldstein D, Hamm J, et al. Erlotinib plus gemcitabine compared with gemcitabine alone in patients with advanced pancreatic cancer: a phase III trial of the National Cancer Institute of Canada Clinical Trials Group. J Clin Oncol. 2007;25(15):1960-66.

37. Escudier B, Eisen T, Stadler WM, et al. Sorafenib in advanced clear-cell renal-cell carcinoma. N Engl J Med. 2007;356(2):125-34. 
38. Llovet JP, Ricci S, Mazzaferro V, et al. Sorafenib in advanced hepatocellular carcinoma. N Engl J Med. 2008;359(4):378-90.

39. Brose MS, Nutting CM, Jarzab B, et al. Sorafenib in radioactive iodinerefractory, locally advanced or metastatic differentiated thyroid cancer: a randomized double-blind phase 3 trial. Lancet. 2014;384(9940):319-28.

40. Dimopolous MA, Chen C, Spencer A, et al. Long-term follow-up on overall survival from the MM-009 and MM-010 phase III trials of lenalidomide plus dexamethasone in patients with relapsed or refractory multiple myeloma. Leukemia. 2009;23(11):2147-52.

41. Trněný M, Lamy T, Walewski J, et al. Lenalidomide versus investigator's choice in relapsed or refractory mantle cell lymphoma (MCL-002; SPRINT): a phase 2, randomized, multicenter trial. Lancet Oncol. 2016;17(3):319-31.

42. Hoyle M, Rogers G, Moxham T, Liu Z, Stein K. Cost-effectiveness of dasatinib and nilotinib for imatinib-resistant or -intolerant chronic phase chronic myeloid leukemia. Value Health. 2011;4(8):1057-67.

43. Motzer RJ, Hutson TE, Tomczak P, et al. Overall survival and updated results for sunitinib compared with interferon alfa in patients with metastatic renal cell carcinoma. J Clin Oncol. 2009;27(22):3584-90.

44. Demetri GD, van Oosterom AT, Garrett CR, et al. Efficacy and safety of sunitinib in patients with advanced gastrointestinal stromal tumor after failure of imatinib: a randomized controlled trial. Lancet. 2006;368(9544):1329-38.

45. Faivre S, Niccoli P, Castellano D, et al. Sunitinib in pancreatic neuroendocrine tumors: updated progression-free survival and final overall survival from a phase III randomized study. Annals Oncol. 2017;28(2) 339-43.
46. Rajkumar SV, Blood E, Vesole D, Fonseca R, Greipp PR. Phase III clinical trial of thalidomide plus dexamethasone compared with dexamethasone alone in newly diagnosed multiple myeloma: a clinical trial coordinated by the Eastern Cooperative Oncology Group. J Clin Oncol. 2006;24(3):431-36.

47. Johnston S, Pippen J, Pivot X, et al. Lapatinib combined with letrozole versus letrozole and placebo as first-line therapy for postmenopausal hormone receptor-positive metastatic breast cancer. J Clin Oncol. 2009;27(33):5538-46

48. Sternberg CN, Hawkins RE, Wagstaff J, et al. A randomized, doubleblind phase III study of pazopanib in patients with advanced and/or metastatic renal cell carcinoma: final overall survival results and safety update. Eur J Cancer. 2013;49(6):1287-96.

49. Motzer RJ, Escudier B, Oudard S, et al. Phase 3 trial of everolimus for metastatic renal cell carcinoma: final results and analysis of prognostic factors. Cancer. 2010;116(18):4256-65.

50. Yao JC, Shah MH, Ito T, et al. Everolimus for advanced pancreatic neuroendocrine tumors. N Engl J Med. 2011;364:514-23.

51. Yao JC, Fazio N, Singh S, et al. Everolimus for the treatment of advanced, non-functional neuroendocrine tumors of the lung or gastrointestinal tract (RADIANT-4): a randomized, placebo-controlled, phase 3 study. Lancet. 2016;387(10022):968-77.

52. Piccart M, Hortobagyi GN, Campone M. Everolimus plus exemestane for hormone-receptor-positive, human epidermal growth factor receptor2-negative advanced breast cancer: overall survival results from BOLERO-2. Ann Oncol. 2014;25(12):2357-62. 


\begin{tabular}{|c|c|c|c|}
\hline \multirow[t]{2}{*}{ APPENDIX A } & \multicolumn{3}{|c|}{$\begin{array}{l}\text { Two-Part Model Predicting } \\
\text { Out-of-Pocket Spending for Oral } \\
\text { Oncolytics: Survival Categorized } \\
\text { by Drug and Indication }\end{array}$} \\
\hline & $\begin{array}{l}\text { Change } \\
\text { Out-of-I }\end{array}$ & $\begin{array}{l}\text { in Mean Monthly } \\
\text { ocket Spending, \$ }\end{array}$ & $P$ Value \\
\hline \multicolumn{4}{|l|}{ Survival benefit } \\
\hline Off-label & & Reference & \\
\hline No benefit & 33.99 & $(-68.02,136.00)$ & 0.510 \\
\hline$>0-5$ months PFS & -2.17 & $(-11.37,7.03)$ & 0.640 \\
\hline$>5-10$ months PFS & 29.42 & $(-30.43,89.28)$ & 0.340 \\
\hline $10+$ months PFS & 19.14 & $(-19.99,58.27)$ & 0.340 \\
\hline$>0-1$ year OS & -21.04 & $(-34.8,-7.27)$ & 0.003 \\
\hline$>1-4$ years OS & 21.89 & $(-44.2,87.96)$ & 0.520 \\
\hline $4+$ years OS & 26.16 & $(-43.46,95.78)$ & 0.460 \\
\hline Year & -3.89 & $(-5.46,-2.32)$ & $<0.001$ \\
\hline Total (plan + patient) payment & 5.28 & $(4.37,6.21)$ & $<0.001$ \\
\hline \multicolumn{4}{|l|}{ Age } \\
\hline $18-35$ & & Reference & \\
\hline $36-45$ & 3.42 & $(-17.22,24.07)$ & 0.750 \\
\hline $46-55$ & 1.76 & $(-8.28,11.80)$ & 0.730 \\
\hline $56-65$ & 0.33 & $(-14.40,15.06)$ & 0.970 \\
\hline \multicolumn{4}{|l|}{ Sex } \\
\hline Male & & Reference & \\
\hline Female & 3.18 & $(-4.24,10.61)$ & 0.400 \\
\hline \multicolumn{4}{|l|}{ Region } \\
\hline Northeast & & Reference & \\
\hline Midwest & 21.07 & $(-2.05,44.18)$ & 0.070 \\
\hline South & 12.07 & $(-2.28,26.43)$ & 0.100 \\
\hline West & 25.77 & $(10.34,41.20)$ & 0.001 \\
\hline Unknown & 76.89 & $(30.15,123.64)$ & 0.001 \\
\hline \multicolumn{4}{|l|}{ Charlson comorbidity score } \\
\hline 0 & & Reference & \\
\hline 1 & 10.21 & $(-26.00,46.42)$ & 0.580 \\
\hline 2 & -47.73 & $(-110.59,15.13)$ & 0.140 \\
\hline $3+$ & -47.93 & $(-110.53,14.66)$ & 0.130 \\
\hline \multicolumn{4}{|l|}{ Health plan type } \\
\hline CDHP/HDHP & & Reference & \\
\hline Comprehensive & -3343.86 & $-25811.27,19123.56)$ & 0.770 \\
\hline $\mathrm{EPO} / \mathrm{HMO}$ & -3696.78 & $28348.36,20954.79)$ & 0.770 \\
\hline POS/POS with capitation & -3268.04 & $-25447.03,18910.95)$ & 0.770 \\
\hline $\mathrm{PPO}$ & -3705.51 & $-28370.51,20959.48)$ & 0.770 \\
\hline Unknown & -952.26 & $(-5612.63,3708.11)$ & 0.690 \\
\hline \multicolumn{4}{|c|}{$\begin{array}{l}\text { Note: Models adjust for all variables in the table. Values are presented as mean, } \\
(95 \% \mathrm{CI}) \text {. } \\
C D H P=\text { consumer-driven health plan; } E P O=\text { exclusive provider organization; } \\
C I=\text { confidence interval; HDHP = high deductible health plan. } H M O=\text { health } \\
\text { maintenance organization; OS= overall survival; } P F S=\text { progression-free survival; } \\
\text { POS = point of service; } P P O=\text { preferred provider organization. }\end{array}$} \\
\hline
\end{tabular}

\begin{tabular}{|c|c|c|}
\hline \multirow[t]{2}{*}{ APPENDIX B } & \multicolumn{2}{|c|}{$\begin{array}{l}\text { Two-Part Model Predicting } \\
\text { Out-of-Pocket Spending for Oral } \\
\text { Oncolytics: Survival Categorized by } \\
\text { Drug's First Approved Indication }\end{array}$} \\
\hline & $\begin{array}{l}\text { Change in Mean Monthly } \\
\text { Out-of-Pocket Spending, \$ }\end{array}$ & $P$ Value \\
\hline \multicolumn{3}{|l|}{ Survival benefit } \\
\hline Off-label & Reference & \\
\hline No benefit & $300.63(-6484.95,7086.20)$ & 0.930 \\
\hline$>0-5$ Months PFS & $159.01 \quad(-3575.37,3893.39)$ & 0.930 \\
\hline$>5-10$ months PFS & $1094.58(-24981.46,27170.62)$ & 0.930 \\
\hline $10+$ Months PFS & $-56.44 \quad(-608.30,495.42)$ & 0.840 \\
\hline$>0-1$ year OS & $-56.47 \quad(-608.20,495.27)$ & 0.840 \\
\hline$>1-4$ years OS & $469.23(-10186.67,11125.13)$ & 0.930 \\
\hline $4+$ years OS & $429.99 \quad(-9226.77,10086.76)$ & 0.930 \\
\hline Year & $(-5.68,-2.03)$ & $<0.001$ \\
\hline Total (plan + patient) payment & $(2.93,6.85)$ & $<0.001$ \\
\hline \multicolumn{3}{|l|}{ Age, years } \\
\hline $18-35$ & Reference & \\
\hline $36-45$ & $(-18.05,19.78)$ & 0.930 \\
\hline $46-55$ & $(-13.93,12.48)$ & 0.910 \\
\hline $56-65$ & $(-18.31,14.64)$ & 0.830 \\
\hline \multicolumn{3}{|l|}{ Sex } \\
\hline Male & Reference & \\
\hline Female & $(-7.04,9.78)$ & 0.750 \\
\hline \multicolumn{3}{|l|}{ Region } \\
\hline Northeast & Reference & \\
\hline Midwest & $(9.94,29.26)$ & $<0.001$ \\
\hline South & $(-6.18,24.12)$ & 0.250 \\
\hline West & $(-23.37,56.67)$ & 0.420 \\
\hline Unknown & $(-37.85,133.47)$ & 0.270 \\
\hline \multicolumn{3}{|l|}{ Charlson comorbidity score } \\
\hline 0 & Reference & \\
\hline 1 & $8.10 \quad(-95.75,111.95)$ & 0.880 \\
\hline 2 & $-87.96 \quad(-298.68,122.77)$ & 0.410 \\
\hline $3+$ & $-88.09 \quad(-298.70,122.52)$ & 0.410 \\
\hline \multicolumn{3}{|l|}{ Health plan type } \\
\hline CDHP/HDHP & Reference & \\
\hline Comprehensive & $-2422.64(-47338.87,42493.59)$ & 0.920 \\
\hline EPO/HMO & $-2626.83(-51439.13,46185.47)$ & 0.920 \\
\hline POS/POS with capitation & $-2564.24(-51006.45,45877.98)$ & 0.920 \\
\hline $\mathrm{PPO}$ & $-2627.59(-51448.48,46193.31)$ & 0.920 \\
\hline Unknown & $-405.97 \quad(-6671.37,5859.42)$ & 0.900 \\
\hline \multicolumn{3}{|c|}{$\begin{array}{l}\text { Note: Models adjust for all variables in the table. Values are presented as mean, } \\
(95 \% \text { CI). } \\
C D H P=\text { consumer-driven health plan; } E P O=\text { exclusive provider organization; } \\
C I=\text { confidence interval; HDHP = high deductible health plan; HMO=health } \\
\text { maintenance organization; OS=overall survival; } P F S=\text { progression-free survival; } \\
\text { POS = point of service; } P P O=\text { preferred provider organization. }\end{array}$} \\
\hline
\end{tabular}

